\title{
Cooperativism, regional and organic products: the Design perspective for the valorization of the Brazilian food sector
}

\author{
Victória Carolina Pinheiro Lopes Dias ${ }^{1 a}$, Daniel de Souza Gamarano ${ }^{2}$ and Davi Neiva Alves ${ }^{3}$ \\ ${ }^{1}$ Universidade do Estado de Minas Gerais, mestrando em Design - victoriacapilo13@gmail.com \\ ${ }^{2}$ Universidade do Estado de Minas Gerais, mestranda em Design - dgdanielgamarano@gmail.com \\ 3niversidade do Estado de Minas Gerais, mestrando em Design - dneivaalves@gmail.com
}

\begin{abstract}
The goal of this paper is to show how some design actions can be used for the valorization regional products from organic production. Therefore, three activities made by family farming cooperatives located into different Brazilian states (Copacaju-CE, Cooperjap-MG, Coopercuc-BA) were analysed. Aiming verify how can the design support the strengthening of identity, community autonomy and products valorization, contributing to their characteristics and values to be perceived by consumers. The research that guides this study has a qualitative exploratory approach. Through bibliographic review of design domain authors Krucken (2009) and Bistagnino (2009) the cooperatives were analysed, evaluating how product characteristics and their correlation with an identity in the territory, the relations of production and commerce, the valorization of the place and the relation of the man and the environment. Observing the results of the analysis, we can see that the action of the design happens in different levels in each cooperative, which may provide support for more assertive future design actions, in the same contexts and in similar contexts.
\end{abstract}

Keywords. Organic food, cooperativism, design, sustainability, identity.

\section{Introduction}

We live a transition period, in which there is more and more worrying from the individuals about the repercussion of their daily behaviors, once the choices we perform, how we act and position about the current socio-environmental problems influence directly into a huge chain of events. There is growing concern about integration of social, environmental and economic levels of human activities, once the personal choices of each person becomes more rigorous facing the current productive reality extremely capitalist and predatory of the natural resources. This way, many companies begin to rethink their products and services as a way to reduce environmental impacts (REIS, 2010).

Since the second half of the 20th century, technological and scientific transformations have resulted in the development of productive processes and the strengthening of consumption practices. In addition, exponential population growth contributes to the triggering of various environmental problems, related to human survival, such as housing, food and water supply, culminating in the expansion of environmental problems such as pollution, burning and deforestation (SEVCENKO, 2001; KAZAZIAN, 2005).

\footnotetext{
${ }^{\mathrm{a}}$ Corresponding author: victoriacapilo13@gmail.com
}

As an example of these productive practices, we have the production of food through agriculture. This has been forming since the neolithic period around 9,000 years ago. Over the years, there have been several transformations, mainly in relation to the relationship between man and the environment.

"In fact, during the second half of the twentieth century, the contemporary agricultural revolution (high motorization-mechanization, selection of varieties of plants and breeds of animals with strong yield potential, extensive use of fertilizers, concentrated feed for livestock and products for the treatment of plants and domestic animals) has progressed vigorously in developed countries and in some sectors of developing countries" (MAZOYER and ROUDART, 2010, p. 27).

Brazil is one of the world leaders in the production and export of agricultural products. It is the first producer and exporter of coffee, sugar, ethanol from sugarcane and orange juice, it leads the ranking of foreign sales of the complex of soybean, bran, oil and grain (MINISTRY OF AGRICULTURE, 2016). The model of large-scale food production adopted in the country is monoculture, which provides for the cultivation of only one type of agricultural product, 
which generates serious impacts on the soil. In this technique of cultivation, it is common to log and burn the planting area, interrupting a natural process of nutrient replacement, leaving the soil poor and consequently decreasing productivity (CARPENEDO; MIELNICZUK, 1990).

In this sort of production, the risk of pests is imminent with an exaggerated use of pesticides, which directly affects an economy and a society, products can be devalued and all production can be put at risk. Monoculture also causes rural exodus, as it reduces the use of labor, causing the gradual disappearance of cultural traditions in rural areas, weakening family farming. The rural exodus can culminate in the agglomeration process in the urban peripheries, harming the quality of life of the population. (MAZOYER and ROUDART, 2010).

Cooperativism shows itself as a possibility of strengthening small producers, facing an unfavorable scenario. It is considered a solidarity economy and resurfaces in the current context as a reaction to unemployment and the loss of basic social guarantees, giving the rural man autonomy. The basic premise of cooperativism is to bring together individuals to exchange benefits from mutual aid. (NAMORADO, 2006).

We can consider as a cooperative, the organization of individuals in a democratic structure, emphasizing selfmanagement and the distribution of resources. Therefore, they work in search of a common good, through organized and standardized structures for production (SCOPINHO, 2007).

This paper, in the first instance, bases the discussions on design and territory, proposed by Krucken (2009), and systemic design by Bistagnino (2009). The Brazilian cooperatives analyzed: Coopercuc, Cooperjap and Cooperapas are formed by small agricultural producers. They were chosen for analysis by their perception and awareness of environmental and social issues. This insight creates an environment conducive to the use of design tools that can support their processes and products. This insight creates an environment conducive to the use of design tools that can support your processes and products. The three cooperatives, contrary to the current logic of production in Brazilian Agriculture, rely on organic production.

\section{Procedures and methods}

In order to base the analysis of the research, a literature review was carried out about methodology and design actions for the valorization of local products. It started from the question of how their concepts could guide aspects inherent to the valorization of the territory. And how these territories could seek the autonomy for their local communities, through the social, cultural and environmental sustainability in the long term. The cooperatives chosen were: Copacaju-CE, Cooperjap-MG and Coopercuc-BA, all distributed in Brazilian Cerrado and Caatinga regions, have the potential to produce organic food. It should be noted that all organizations had the contribution of design to the conception of products, at various levels, from the revitalization of visual identity and packaging, to the repositioning of products in the domestic and external market.

The three cooperatives are part of the Caatinga and Cerrado Eco Productive Communities Network, a space of articulation formed since 2006 that seeks to create networks among producers of family agriculture for the promotion of products from these two biomes, so characteristic of the country. Currently, Caatinga and Cerrado operate in a universe of more than 20 thousand families, represented in 200 projects in 20 networks located in 14 Brazilian states, as shown in Figure 1:

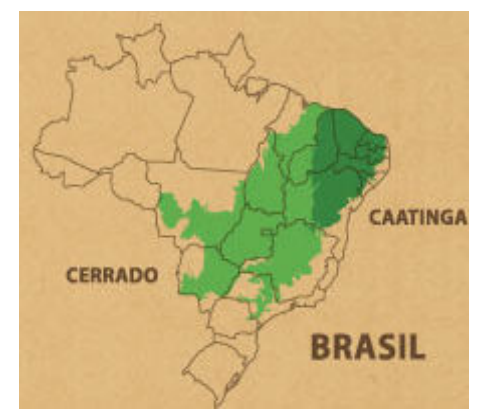

Figure 01: Action network of the Caatinga Cerrado Eco Productive Communities in the country

Source: http://www.caatingacerrado.com.br/

In addition, Rede Caatinga and Cerrado Eco Productive Communities has partnerships with the Brazilian federal government and international nongovernmental organizations. The main objectives of this organization are articulation, communication, capacity building and access to markets. In addition, they have the job of encouraging the certification of enterprises, such as the organic production seal, and the defense of fair trade (CAATINGA CERRADO, 2012). The following chart lists the information for each cooperative:

\begin{tabular}{|c|c|}
\hline $\begin{array}{c}\text { Cooperative/ Place of } \\
\text { origin }\end{array}$ & Description \\
\hline Copacaju/ Ceará & $\begin{array}{c}\text { Central cooperative, } \\
\text { which concentrates on } \\
\text { processing of cashew } \\
\text { nuts. Gives the } \\
\text { opportunity to sellers to } \\
\text { become entrepreneurs. }\end{array}$ \\
\hline
\end{tabular}




\begin{tabular}{|c|c|}
\hline $\begin{array}{c}\text { Cooperjap/ Minas } \\
\text { Gerais }\end{array}$ & $\begin{array}{c}\text { Cooperative of rural } \\
\text { producers and pequi } \\
\text { pickers, were a first unit } \\
\text { of beneficiation of the } \\
\text { fruit in the country, today } \\
\text { they produce in wide } \\
\text { scale. }\end{array}$ \\
\hline Coopercuc / Bahia & $\begin{array}{c}\text { Cooperative that works } \\
\text { with the processing of } \\
\text { Caatinga typical fruits, } \\
\text { mainly the umbu. }\end{array}$ \\
\hline
\end{tabular}

Chart 1: Descriptive of the cooperatives analyzed. Source: Prepared by the authors.

\section{Theoretical reference}

\subsection{Cooperativism}

The labor force is the essence of the productive system, the workers as holders of this force, united, can generate new production possibilities. One of the ways for workers to unite is through cooperativism. There are several forms of cooperativism, such as credit, education, housing, infrastructure, health, tourism, transportation, mineral, farming, production, consumption, agriculture, among others. Cooperativism carried out on agricultural bases helps producers to have easy access to the purchase of inputs and machines, which greatly improves their reality (ONOFRE, ONOKO, 2011).

Agricultural cooperatives are identified as a factor of economic organization and competitiveness of the agrarian sector and of the democratic organization of producers, contributing to the success of local development projects. Its importance can be highlighted in the current scenario, with the search for new improvements in an environment that has suffered from the globalization process, which in seeking a mass production, mechanized the countryside, causing the weakening of family agriculture and the increase of rural exodus. Thus, new forms of appreciation of typical and symbolic goods must be worked and promoted, and these are capable of expressing the dynamism of a community in the face of the current scenario. It should be noted that cooperativism allows adaptation to different types of demands (MARTÍNEZ; PIRES, 2002).

\subsection{Design and Territory}

There is a current demand that seeks to consume products that bring within them intangible values, such as tradition and cultural identity, while promoting a better quality of life for the rural man. When analyzing the Brazilian context, one can perceive the significant wealth of its culture, knowledge, people, and customs, as well as the natural riches coming from the territory. This wealth promotes the promotion of the production of material goods strongly linked to the origin and the local community (KRUCKEN, 2009). "However, often the existing resources are not exploited in a sustainable way (economic, social and environmental) and do not generate wealth and improvement of life of the local community" (KRUCKEN, 2009, p.22). The design approach to land-based issues brings benefits to consumers and producers alike. Actions can be planned for territory promotion and for society in a way that is sustainable in the long run. From the theoretical assumptions of Krucken's research, design can contribute to the valorization of local products from eight essential actions, in chart 2:

\begin{tabular}{|c|c|c|}
\hline 1 & Recognize & $\begin{array}{c}\text { the qualities of the product and } \\
\text { the territory; }\end{array}$ \\
\hline 2 & Enable & competences within the territory; \\
\hline 3 & Communicate & the product and the territory; \\
\hline 4 & Protect & $\begin{array}{r}\text { local identity and tangible and } \\
\text { intangible heritage; }\end{array}$ \\
\hline 5 & Support & $\begin{array}{r}\text { local production; } \\
\text { products; }\end{array}$ \\
\hline 6 & Promote & $\begin{array}{r}\text { production system for sustainable } \\
\text { new products and services that } \\
\text { territory; }\end{array}$ \\
\hline 7 & Develop & $\begin{array}{r}\text { respect the vocation and value the } \\
\text { networks in the territory. }\end{array}$ \\
\hline 8 & Consolidate & r \\
\hline
\end{tabular}

Chart 2: Points of valorization of local products by Design. Source: Adapted from Krucken (2009).

\subsection{Systemic design}

Industrialization has shifted the process of designing the product also into food. For Bistagnino (2009), nature should be considered as a system to be understood and followed, since processes in ecosystems work in a way 
that promotes mutuality and complementarity.

Design professionals must work in a way to think of the same connections applied to the production processes, not only considering the final product, but all of its manufacturing process, from obtaining the raw material to its disposal. In order to understand how is the interlocution of actors who share the same values. For this, the author claims to be the designer, responsible for the interpretation of the bases, for example, of the inputs and outputs of the system, since they can suggest advantageous connections and interactions, new uses of matter, new possibilities and forms of energy generation (Bistagnino, 2009). It is indispensable to apply simultaneous actions, capable of developing sustainable thinking. The author considers five basic lines for the development of systemic design, being presented in chart 3. The research group on Systemic Design has support from the Slow Food movement.

\begin{tabular}{|c|c|c|}
\hline 1 & Output/Input & $\begin{array}{c}\text { The discards of one system } \\
\text { may become the resources } \\
\text { of the other. }\end{array}$ \\
\hline 2 & Relations & $\begin{array}{c}\text { Relationships can be } \\
\text { internal or external to the } \\
\text { focus system and all are } \\
\text { strategic elements. }\end{array}$ \\
\hline 3 & Self-generation & $\begin{array}{c}\text { The autopoietic system } \\
\text { sustains and reproduces } \\
\text { autonomously, defining its } \\
\text { own field of action. }\end{array}$ \\
\hline 4 & Act locally & $\begin{array}{c}\text { In the context where one } \\
\text { works to value the local } \\
\text { researches the man, culture } \\
\text { and matter. }\end{array}$ \\
\hline 5 & $\begin{array}{c}\text { Man as the } \\
\text { center of the } \\
\text { project }\end{array}$ & $\begin{array}{c}\text { The individual related to } \\
\text { the environmental, social, } \\
\text { cultural and ethical context. }\end{array}$ \\
\hline
\end{tabular}

Chart 3: Basic lines of Systemic Design.

Source: Adapted from Bistagnino (2009).

\subsection{Slow Food movement}

Slow Food is currently an international non-profit association. The primary concept of the movement is the pleasure of food. As well as disseminating knowledge, educational projects, allowing practices that value the local production (SLOW FOOD BRAZIL, 2013).
Among the initiatives proposed by the movement in Brazil, we highlight the Food Communities, which are physically identifiable productive units, which share the interest in valuing artisanal production. Among the cooperatives studied, two are considered Food Communities, Cooperjap-MG and Coopercuc-BA.

\subsection{Certifications}

Certifications are of the utmost importance to cooperatives, since they qualify and demonstrate the conformity of production through the criteria that are analyzed. Thus, the demand for compliance with regulations regarding organic production, fair trade, or participation in some institution or movement, such as Slow Food, validate the product quality.

Organic food is by definition, any product produced and cultivated that considers the three levels of sustainability, social, environmental and economic. Organic agriculture does not make use of agrochemicals, veterinary hormones, chemical fertilizers, antibiotics or transgenic specimens at any stage of production. In order to obtain the national seal, the company must be evaluated (MINISTRY OF AGRICULTURE, 2016).

Fair Trade is a partnership based on dialogue, transparency and respect. Seeking greater equality in international trade, by ensuring fair conditions and valuing workers' production (SEBRAE NACIONAL, 2016). The importance of Fair Trade is the establishment of direct contact between the producer and the buyer, debureaucratization the trade and the action of the middlemen. Cooperatives encourage the collective construction of knowledge, which contributes to production planning, quantity, quality and regularity, as well as a better selling price for products (GIRÃO et al., 2009; SEBRAE NACIONAL, 2016).

\section{Analyses of cooperatives}

\subsection{Copacaju - Ceará}

The Copacaju Cooperative Center is an entity that unites ten distinct cooperatives, distributed in cities of Ceará. The work takes place from the processing of cashew nuts, which takes place in mini factories. (CAATINGA AND CERRADO, 2012). The creation and formalization of the cooperative was extremely important, it allowed the certification and qualification of the cashew as familiar and organic, which would open the way for the export of the product. In addition, the project ensured the creation of a visual identity (GIRÃO et al., 2009).

The company responsible for the new packaging of nuts was Herbert Perman Design, a Recife office, which develops visual identity projects, signage, graphic design, point of sale material and packaging. Copacaju 
intends to export the nuts, and for that, it has made packages that present the product in different forms, in the options pre-cooked, toasted and salted, with caramel and with chocolate, as shown in figure 2 :

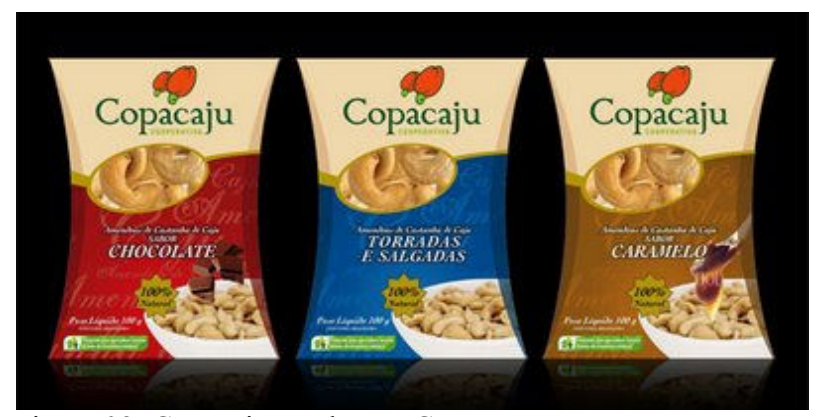

Figure 02: Copacaju Products - Ceará

Source:http://portfoliomike.blogspot.com.br/2006/02/embalage ns.html

\subsection{Cooperjap - Minas Gerais}

Cooperjap, Cooperative of rural producers and pickers of pequi from Japonvar, is located in the northern region of Minas Gerais. In 1998, local people decided to create the cooperative in order to institutionalize the processing of the fruit of the region, transforming it into pulp, oil, flour, paçoca and cream, and other products. They were the first fruit processing unit in the country and were supported by institutions such as SEBRAEMG, UFMG, Japonvar prefecture and Emater-MG, which contributed to the development of control and production technologies. The whole process was structured and fully implemented only in 2005, when the cooperative began to produce pequi on a large scale (ALMEIDA, 2009).

There are more than 210 cooperatives, who benefit from the pequi crop. The cooperative guarantees new business contacts, especially with participation in events, visibility and recognition of the work, and causes new partnerships to emerge (ALMEIDA, 2009).

The design project was conducted by Quantum Design, located in Belo Horizonte, MG (QUANTUM DESIGN, 2016).

The project carried out together with Cooperjap went beyond the revitalization of the cooperative's visual identity and packaging labels, promoted the standardization of weights and measures of the products sold, focusing on those that had a greater commercial representativeness (SILVA E BENATTI, 2011). The final result was the product line represented in figure 3 :

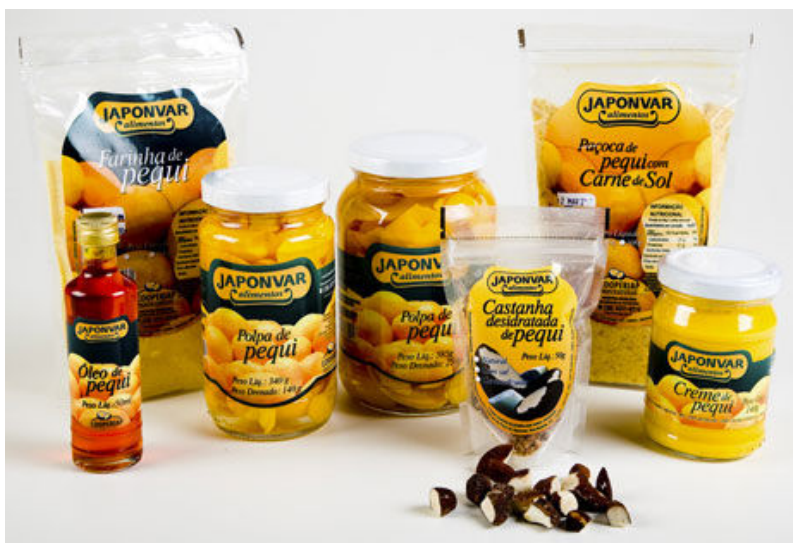

Figure 03: Cooperjap products - Japonvar Source:http://www.centraldocerrado.org.br/comunidades/coope rjap/

\subsection{Coopercuc - Bahia}

The history of Coopercuc (Cooperative of Uauá, Curaçá and Canudos) begins in 1980, in the city of Uauá, located in the backlands of Bahia, in the northeastern region of Brazil. A group of three nuns began working with the community, encouraging the participation of women in order to promote greater autonomy in local political decisions and increase in family income. Thus, from the domestic tasks and the care of animals and vegetable gardens, women began to collect the fruits of the Caatinga region. The movement was articulated, and the neighboring cities, Curaçá and Canudos, joined the movement. In the 1990s, the group already knew how to benefit the fruits and market them. (COOPERCUC, 2015).

The cooperative was officially made in 2004. The company founded by the cooperative, known as Gravetero, produces jams, juices and sweets in fruit paste such as guava, mango, banana, passion fruit and especially the umbu, typical of the Caatinga region, as shown in figure 4. Currently the company has the support of Slow Food Brasil, which allowed international non-governmental organizations to invest in the construction of sixteen mini-factories distributed in the three cities. The company is certified for the marketing of organic products by the European Union, which allowed $25 \%$ of production to be exported to France, Italy and Austria. (MARTINS, 2016). 


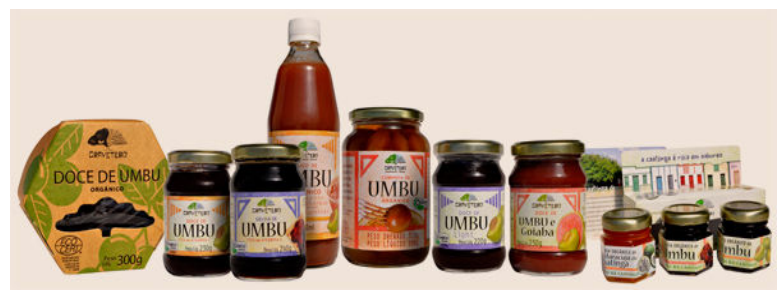

Figure 04: Coopercuc products - Gravetero

Source:http://www.coopercuc.com.br/produtos/catalogo-deprodutos-gravetero/

Despite its main activity is the extraction of umbu, the company also contributes to the region's development, promoting the planting of umbu trees seedlings in order to increase production and preserve the species (COOPERCUC, 2015).

The company responsible for the production of packaging and graphics of Coopercuc was the office DoDesign Brasil, founded in 2003. It is specialized in organic businesses, gourmet foods and projects that involve socio-biodiversity, having projects focused on organic and agroecological agriculture. It has several prizes, such as the Slow Pack by Slow Food Italy in 2014 (DODESIGN BRASIL, 2015).

\section{Conclusions}

In general, the creation of a network that values producers of local typical food establishes itself against a capitalist productive reality that tends to massify the production and availability of food. The organization of these producers in cooperatives, besides supporting the production and commercialization of the product, allows a production that, in several levels, contributes to the economic, social and environmental sustainability of that group. The cooperatives support the formation of networks with external agents, of various expertises, that can help to the development of the group. This is the case, for example, of the monitoring received from agencies for the administration and production of food, the participation in similar groups of companies, such as the Caatinga and Cerrado Eco Productive Communities. The design, not only acts in the elaboration of the visual identity, packaging and presentation of products, but also acts strategically throughout the system, ensuring process improvements in knowledge management. As well as the incorporation of new concepts, products and services.

Among the cooperatives analyzed, it can be seen that Copacaju is in the process of adapting the product in order to increase sales. Up to now, it has received occasional design interventions, mainly materialized in the development of its packaging, when compared to the other two cooperatives. It is interesting to note that evaluating it, its internal and external relations should be strengthened in a network in order to better promote the brand's identity in relation to the public.

Cooperjap already has certifications and participates in national and international events that give visibility to the products and generate partnerships. The success of the cooperative is due to its transdisciplinary stance by seeking support from other institutions that hold the knowledge and professionals with various expertise, which configures its systemic view of the process. These institutions contribute to the planning and take actions, taking advantage of all the potential of the territory, improving the product, process and its communication for the search of new opportunities.

Coopercuc is in a similar stage to Cooperjap, both participating in the Slow Food network. Its success is due to a wide network of partners and its transdisciplinary stance. The food produced by the cooperatives tends to be fully utilized, as an example to Cooperjap, which produces products with pequi. Coopercuc's thinking of exploring production, by starting to plant new seedlings of umbu to ensure future production, as well as the willingness of those involved to pass on knowledge to other producing communities. This demonstrates the perception of the local act and the appreciation of human work. Copacaju values the development of employees, giving them autonomy in the production of the product. Although each cooperative tangentially differentiates the guidelines proposed by Bistagnino (2009), it is emphasized that all have environments that can be created and valued relationship networks.

The importance of analyzing cooperatives from the perspective of design is due to the identification of the paradigms, evaluating whether the actions taken are of short or long term, and verifying how these methodologies are being applied. From the analysis of this phenomenon we can observe practices that can serve as a guide for future actions in contexts similar to those of cooperatives, allowing future projects to be more assertive and can actually collaborate to improve the quality of life of these people.

This paper had a reflexive character about the performance of the design in the context of the cooperatives. Future studies can glimpse the follow-up of design actions based on the authors Bistagnino (2009) and Krucken (2009) within the context studied.

\section{References}

ALMEIDA, S. O ouro do Cerrado Mineiro. Revista Passo a passo, março/abril - ano XV- $\mathrm{n}^{\circ} 131$. Belo Horizonte: Sebrae -MG, 2009. 
BISTAGNINO, L. Design Sistemico. Progettare la sostenibilità produttiva e ambientale. Slow Food Editore, Torino. 2009.

CAATINGA \& CERRADO. Site oficial Disponível em $<$ http://www.caatingacerrado.com.br/>. Acesso 08 Dez. 2016.

CARPENEDO, V.; MIELNICZUK, J. Estado de agregação e qualidade de agregados de Latossolos Roxos, submetidos a diferentes sistemas de manejo. Revista Brasileira de Ciência do Solo, Campinas, v.14, n.1, p.99-105, jan./abr. 1990.

COOPERCUC. Site oficial. Disponível em

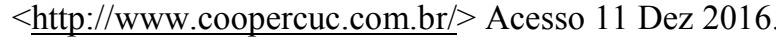

DODESIGN BRASIL. Site oficial. Disponível em $<$ https://www.dodesign-s.com.br/design/publicacoes/ > Acesso 07 Dez. 2016.

GIRÃO, E.G.; OLIVEIRA, F.L.; KUSTER, A. PEREIRA, J.I.C. A transição agroecológica familiar no município de Barreira, Ceará, Brasil. Revista Brasileira de Agroecologia/nov 2009. Vol.4. No. 2.

KAZAZIAN, T. Haverá a idade das coisas leves. São Paulo, Editora Senac , 2005.

KRUCKEN, Lia. Design e território: valorização de identidades e produtos locais. São Paulo: Studio Nobel, 2009 .

MARTÍNEZ, I; PIRES, M. Cooperativas e revitalização dos espaços rurais: uma perspectiva empresarial e associativa. Cadernos de Ciência \& Tecnologia, Brasília, v.19, n.1, p.99-118, jan/abr 2002.

MARTINS, M. G. Cooperativismo, agroindústria da agricultura familiar e mercado: um estudo de caso da Coopercuc/BA, 2016. Tese de Mestrado do Programa de Pós graduação em Agronegócios da Faculdade de Agronomia e Veterinária da Universidade de Brasília (UnB).

MAZOYER, M.; ROUDART,L. História das agriculturas no mundo: do neolítico à crise contemporânea. São Paulo, Editora UNESP; Brasília, DF, 2010.

$\begin{aligned} & \text { MINISTÉRIO DA AGRICULTURA, O que é um } \\ & \text { alimento } \\ & \text { orgânico? }\end{aligned}$
<http://www.agricultura.gov.br/portal/page/portal/Intern
et-MAPA/pagina-inicial/desenvolvimento-
$\underline{\text { sustentavel/organicos/o-que-e-agricultura- }}$
$\underline{\text { organica/perguntas-e-respostas }>\text { Acesso } 10}$ Dez. 2016.

NAMORADO, R. Cooperativismo - um horizonte possível, 2005. Videoconferência, Coimbra. Disponível em

$<$ http://www.ces.uc.pt/publicacoes/oficina/ficheiros/229. pdf> Acesso 08 Dez. 2016.

ONOFRE, G. R.; YOKOO,S.C. Cooperativismo Rural Revista GEOMAE - Geografia, Meio Ambiente e Ensino. Vol. 02, No 01, $1^{\circ}$ SEM/2011 p.103-101

REIS, D. Product Design in the sustainable era. Editora Taschen GmbH, Hohenzollernring, Alemanha, 2010.

SCOPINHO, R. A. Sobre cooperação e cooperativas em assentamentos rurais. Psicol. Soc. [online]. Vol.19, n.spe, pp. 84-94, 2007.

SERVIÇO BRASILEIRO DE APOIO ÀS MICRO E PEQUENAS EMPRESAS (SEBRAE NACIONAL). O que é Fair Trade (Comércio Justo) 2016. Disponível em

$<\underline{\text { https://www.sebrae.com.br/sites/PortalSebrae/artigos/o- }}$ que-e-fair-trade-comerciojusto, 82d8d1eb00ad2410VgnVCM100000b272010aRC $\underline{\mathrm{RD}}>$ Acesso 08 Dez. 2016.

SEVCENKO, N. A corrida para o Século XXI: no Loop da Montanha Russa. São Paulo: Companhia das Letras, 2001.

SLOW FOOD BRASIL 2013. Site oficial. Disponível em: $<$ http://www.slowfoodbrasil.com/> Acesso $11 \mathrm{Dez}$ 2016.

SILVA, A.C.M.; BENATTI, L.P. Ergonomia em projeto gráfico: embalagem para produto alimentício tradicional. $11^{\circ}$ Ergodesign USIHC, Manaus, 2011.

QUANTUM DESIGN, 2016. Disponível em $<$ http://www.quantumdesign.com.br/>. Acesso 08 Dez. 2016. 